\title{
STRATEGI KOMUNIKASI PENANGANAN PEMINDAHAN PASAR TIBAN DI KOTA PEKALONGAN
}

\author{
Communication Strategy of Pasar Tiban Relocation in Pekalongan \\ Trimanah dan Mubarok ${ }^{1}$ \\ Fakultas Ilmu Komunikasi Universitas Islam Sultan Agung Semarang
}

\begin{abstract}
Pekalongan is one of the citiesin Indonesia that undergo arapid development in various fields. One of thestands out economic activity of the town is Pasar Tiban. Pasar Tiban is a term used for a traditional market which opened without any legal approval from the local government. Based on the data taken from Disperindagkop and UMKM Pekalongan, there are 28 pasar tiban spread across the city in 2014. Eventhough it is ilegal, somehow it moves the informal sector of the city.

However,its development has caused social problems such astraffic jam, disorder, anddiscomfort. Its existencehas violatedthe ActNo.22of 2009 on Traffic and Transportation (LLAJ Law), Article number 275 paragraph (1) in conjunction with Article 28 paragraph (2), and Act No. 22 of 2009, which regulates the use of the road and side walk. In- depth research has to be done in order to findthe best solutionto overcomethe phenomenonof Pasar Tiban. The purpose of this study is to create a communication strategy to relocate Pasar Tiban without neglecting the interests of traders and communities. This research was conducted by combining quantitative and qualitative research methods. Quantitative data are obtained from the questionnaire, where as qualitative data are obtained from in-depth interviews as well as field observations.

The result showsthe importance of coordination and unity among local leaders, SKPD, and Police so that the relocation can be done without any friction. Although most traders do not agree with therelocation there are some traderswho are willing tobe relocated if the concept and the srtucture if the new area is good enough and able to improve their we lf are. In a communication strategy, theobjectives of an action should be clearly defined so that the traderscould easily accept, understand, and are willing to follow all the stages needed for the relocation. The selected communication strategy includes fourt actics, namely; Interpersonal communication, Organizational media, Newsmedia, Advertising and Promotional Media Tactic. All of them will be running perfectly if the objectives was cleary explanied and full support from the stakeholders.
\end{abstract}

Keyword: Pasar Tiban market, strategy, communication, relocation

1 Untuk korespondensi dengan penulis, Trimanah bisa dihubungi di trimanah @unissula.ac.id dan Mubarok di mubarok@unissula.ac.id. Alamat kantor Fakultas Ilmu Komunikasi JL. Kaligawe Km 4 Semarang (024) 6583584 ext 449 


\section{PENDAHULUAN}

Kota Pekalongan yang terletak di pantai utara Jawa merupakan salah satu kota yang mengalami perkembangan pesat di berbagai bidang. Posisinya yang strategis membuat daya tarik kota ini terus meningkat setiap tahunnya. Kota Pekalongan berada di jalur Pantura yang dikenal sebagai jalur transportasi dan distribusi utama Pulau Jawa. Pertumbuhan ekonomi di kota pesisir ini dipengaruhi oleh beberapa faktor diantaranya peningkatan sektor usaha, peningkatan investasi perhotelan, pariwisata, perikanan, dan sektor jasa. Berdasarkan data dari BPS, jumlah penduduk Kota Pekalongan mencapai 290.347 pada tahun 2012. Pertumbuhan ekonomi kota yang relatif tinggi membuat potensi perkembangan usaha semakin besar.

Meningkatnya daya tarik ekonomi kota Pekalongan membuat orang dari berbagai daerah lain tertarik untuk mengadu nasib di kota ini. Tidak semua pencari kerja mampu diserap oleh lapangan kerja formal yang tersedia. Akibatnya banyak diantara pendatang yang memilih menekuni sektor informal seperti menjadi pedagang kaki lima, pedagang pasar tiban, dan profesi informal lainnya. Di satu sisi perkembangan potensi ekonomi akan meningkatkan taraf hidup warganya, di sisi lain juga diikuti dengan munculnya permasalahan sosial yang harus diatasi.

Sektor informal menjadi salah satu aktivitas penting perkotaan yang membentuk elemen kota (Nitisudarmo, 2009, Yatmo, 2009 dalam Brotosunaryo dkk, 2013). Kantung-kantung sektor informal banyak menempati lokasi-lokasi strategis seperti kawasan perdagangan, permukiman, perkantoran, kawasan industri hingga fasilitas-fasilitas umum. Bentuk sektor informal dapat dipilah menjadi 2 (dua), yakni (a) sektor informal yang bersifat legal yang biasanya menempati lokasi yang ditentukan oleh pemerintah daerah setempat dan dibuka secara kontinu dan (b) sektor informal yang dilakukan secara illegal, menempati tempat usaha yang tidak ditentukan oleh pemerintah daerah setempat sebagai lokasi sektor informal.

Salah satu kegiatan ekonomi warga yang menonjol adalah maraknya pasar tiban di kota Pekalongan. Berdasarkan data Disperindagkop \& UMKM Kota Pekalongan pada tahun 2014 terdapat 28 lokasi pasar tiban yang tersebar di berbagai tempat. Kegiatan pasar dadakan ini diantaranya berlokasi di Jalan Veteran Kraton (sekitar RS Kraton), Buaran, Tirto dan wilayah lain di kota Pekalongan. Pasar tiban menjadi fenomena ekonomi yang khas di kota Pekalongan. Mereka secara simultan menggelar dagangan berpindah-pindah tempat sesuai jadwal yang berjalan secara konvensi alamiah. Dalam rentang waktu tujuh hari dalam seminggu setidaknya dalam satu hari terdapat 3-5 titik lokasi yang menggelar pasar tiban secara bersamaan. Kegiatan ekonomi di pasar tiban biasanya dimulai pada pukul 16-0022.00 wib. Di beberapa tempat ada pasar tiban yang dilangsungkan di pagi hari.

Kegiatan pasar tiban sebagai pengembangan sektor informal menjadi mata pencaharian dari penduduk baik yang berasal dari kota Pekalongan maupun datang dari luar kota. Keberadaan mereka telah menjadi bagian dari dinamika kehidupan ekonomi di kota Pekalongan. Bergeraknya sektor riil melalui usaha kecil dan menengah membuka lapangan kerja bagi mereka yang tidak terserap di sektor formal. Namun demikian perkembangan pasar tiban yang massif tanpa diikuti dengan konsep penataan yang terarah telah menimbulkan permasalahan sosial, lalu lintas, ketertiban, kenyamanan dan toleransi antara penduduk setempat, pedagang dan pengguna jalan.

Undang-Undang No 22 Tahun 2009 tentang Lalu Lintas dan Angkutan Jalan 
(UU LLAJ) Pasal 275 ayat (1) jo pasal 28 ayat (2), secara jelas menyebutkan; Setiap orang yang mengakibatkan gangguan pada: fungsi rambu lalu lintas, Marka Jalan, Alat pemberi isyarat lalu lintas fasilitas pejalan kaki, dan alat pengaman pengguna jalan. Pelanggar aturan tersebut dikenai Denda Rp250.000. Fungsi trotoar pun diatur dalam Undang-Undang Nomor 22 Tahun 2009, yang melarang penggunaan badan jalan dan trotoar sebagai tempat parkir dan usaha dalam bentuk apa pun. Larangan tersebut juga diatur dalam Undang-undang Nomor 38 Tahun 2004 serta Peraturan Pemerintah Nomor 34 Tahun 2006 tentang Jalan. Dalam beleid itu terdapat ketentuan pidana yang sangat tegas, 18 bulan penjara atau denda Rp1,5 miliar bagi setiap orang yang sengaja melakukan kegiatan yang mengakibatkan terganggunya fungsi jalan dan trotoar.

Pedagang pasar tiban di Kota Pekalongan tidak hanya memanfaatkan trotoar jalan sebagai tempat berjualan, mereka juga memanfaatkan setengah bahu jalan. Di beberapa tempat mereka juga memenuhi semua bagian jalan sehingga sulit bagi pengguna jalan untuk melintas. Tindakan ini jelas bertentengan dengan UU Tentang Lalu Lintas dan Angkutan Jalan yang mengatur fungsi trotoar dan jalan. Karena itu diperlukan sebuah upaya penataan yang mampu memecahkan persoalan ekonomi dan lalu lintas sekaligus. Tujuan penelitian ini adalah: tersusunnya strategi komunikasi penanganan pasar Tiban dengan tetap memperhatikan kepentingan pedagang dan masyarakat lainnya.

\section{METODE PENELITIAN}

Penelitian ini menggabungkan metode kualitatif dan kuantitatif. Untuk memperoleh data penelitian dilakukan: (1) observasi lapangan diperlukan untuk mengetahui kondisi pasar tiban, suasana, arus lalu lintas, perparkiran dan aspek lainnya terkait keberadaan pasar tiban. (2) Wawancara mendalam dengan pimpinan instansi terkait di Kota Pekalongan, wawancara dengan pedagang pasar tiban bermanfaat untuk mengetahui keinginan, harapan, ide, gagasan tentang keberadaan pasar tiban, wawancara dengan pengunjung dan konsumen pasar tiban merupakan kelengkapan gambaran dari sisi lain, wawancara dengan penduduk setempat dan pengguna jalan akan menghasilkan gambaran tentang opini, pendapat, keberatan, ketidaknyamanan, gangguan ketertiban, keamanan yang mungkin timbul dari pelaksanaan pasar tiban. Penyebaran kuesioner kepada pedagang pasar tiban dan masyarakat di sekitar lokasi pasar dimaksudkan untuk mendapatkan data kuantitatif sebagai pelengkap data wawancara yang telah dilakukan. Analisa data kualitatif diawali dengan membuat transkrip hasil wawancara, mengelompokkan jawaban responden yang sama/sejenis, menerjemahkan jawaban responden yang menggunakan bahasa kiasan, mengalihbahasakan jawaban responden kedalam bahasa Indonesia, memilah jawaban yang tidak relevan dengan topik penelitian, membuat kategorisasi jawaban responden, melakukan analisa hasil wawancara. Data hasil wawancara dianalisa untuk mengetahui gambaran mendalam tentang kondisi pasar tiban saat ini. Gambaran dimaksud diantaranya arah kebijakan, tugas pokok dan fungsi dari masing instansi, gambaran kordinasi dan komunikasi antar instansi. Data wawancara dengan pedagang akan memberikan gambaran opini, harapan, usulan terkait pelaksanaan pasar tiban. Data wawancara dengan masyarakat akan memberikan kelengkapan keluhan, harapan, ide, dan sumbangsih pemikiran sebagai bagian dari keterlibatan masyarakat. Data hasil kuesioner bermanfaat untuk generalisasi hasil penelitian sekaligus melengkapi data kualitatif yang telah diperoleh. Data hasil kuesioner dianalisa 
dengan statistik deskriptif maupun inferensia.

\section{HASIL PENELITIAN}

Berdasarkan hasil observasi, pedagang pasar tiban bisa dibagi menjadi beberapa tipologi yang dibedakan berdasarkan status kepemilikan prasarana dan sarana usaha, jenis dan asal produk, dan ciri lokasi usaha. Pemahaman terhadap berbagai tipologi pasar tiban ini bisa menjadi dasar lahirnya kebijakan penanganan pasar tiban yang lebih efektif dan tepat sasaran. Kebijakan-kebijakan penanganan pasar tiban yang dilakukan selama ini cenderung melihat pasar tiban sebagai kategori yang homogen dan mengabaikan keragaman yang ada. Berbagai hal tersebut dapat berkontribusi terhadap kegagalan penanganan pasar tiban. Pedagang pasar tiban terdiri dari pedagang dengan modal besar dan kecil. Pedagang bermodal besar memiliki sarana dan prasarana usaha sendiri. Mereka memiliki lapak dagang, beberapa pedagang menggunakan mobil bak terbuka untuk mengangkut dagangan. Pedagang yang lain menggunakan gerobak yang ditarik dengan sepeda motor. Jenis usaha dagangan seperti pakaian pada umumnya dimiliki pedagang bermodal besar, mereka mampu membuat lapak sendiri. Sebagian pedagang kecil menggunakan lokasi tanpa lapak memadai, mereka memanfaatkan meja kecil atau menggelar dagangan. Tingkat pendidikan dari pedagang juga bervariasi. Ada pedagang yang menyelesaikan pendidikan di tingkat sekolah dasar, ada juga yang menyelesaikan pendidikan di tingkat perguruan tinggi. Pedagang yang menyelesaikan pendidikan di tingkat sekolah dasar rata-rata sudah berusia tua dan telah berdagang lebih dari 5 tahun. Sedangkan pedagang yang berpendidikan tinggi adalah sosok muda yang baru berdagang dan memilih sector perdagangan sebagai lapangan pekerjaan.
Observasi lapangan dilakukan di beberapa lokasi yang digunakan sebagai tempat pasar tiban. Jenis dagangan yang digelar sepanjang jalan meliputi kuliner, pakaian, aksesoris, CD, dan kebutuhan sehari-hari lainnya. Praktek jual beli sepanjang sore hingga malam tersebut diwarnai dengan beberapa catatan. Pertama, ketika pedagang mulai berdatangan di sore hari tidak nampak ada petugas resmi dari pemerintah yang sudah berada di lokasi untuk mengatur posisi pedagang. Mereka menggelar dagangan sesuai dengan kebiasaan lokasi yang mereka tempati. Menjelang malam pengunjung yang berdatangan semakin banyak, disinilah gangguan lalu lintas mulai muncul. Posisi pedagang yang menjorok ke tengah, beberapa pedagang pakaian menggunakan tenda cukup besar, dan perilaku pembeli yang tidak tertib membuat kondisi jalan semakin semrawut. Sepanjang jalan lokasi pasar tiban terdapat beberapa fasilitas publik diantaranya masjid, rumah sakit, pertokoan, sekolah. Beberapa pedagang menggelar lapaknya tepat di posisi kanan dan kiri rumah sakit sehingga mengganggu gerak kendaraan yang keluar maupun masuk ke rumah sakit. Kondisi seperti ini tentunya tidak bisa dibiarkan terus-menerus karena akan mengganggu aktifitas di rumah sakit.

Pembeli yang menggunakan sepeda motor biasa berhenti tepat di depan lapak jualan yang dituju. Pembeli yang menggunakan mobil beberapa juga berhenti di dekat lapak penjual sehingga membuat jalan semakin sempit. Beberapa pembeli yang tertib mencoba memarkir kendaraannya di lokasi yang ada sehingga tidak mempersempit kondisi jalan. Salah satu lokasi yang berhasil ditata adalah pedagang pasar tiban di JL. Teratai. Para pedagang dipindah ke lapangan Sorogenen. Keberhasilan penataan pedagang di lapangan Sorogenen bisa menjadi contoh kesuksesan pemerintah menata pedagang pasar tiban. Pedagang pasar Sorogenen 
adalah pindahan dari Jl.Teratai. Pemerintah berhasil merelokasi mereka dengan baik sehingga bersedia pindah ke lapangan Sorogenen. Hal ini menunjukkan keberhasilan program dan strategi komunikasi yang dijalankan. Keberhasilan penataan pedagang di lapangan Sorogenen tidak lepas dari kesadaran pedagang dan kemampuan pendekatan yang bagus dari pemerintah kota.

Hasil wawancara dan observasi menghasilkan beberapa persoalan utama:

1) Pentingnya arah yang jelas dan kesatuan kata diantara pimpinan daerah untuk mendorong terlaksananya pengelolaan pasar tiban

2) Butuh kebijakan yang jelas dan nyata tentang arah penataan pasar tiban, apakah relokasi, penataan tanpa relokasi, pembubaran atau langkah lainnya

3) Penguatan kordinasi antar instansi sehingga ada kesatuan kata dalam penanganan pasar tiban. Hal ini akan mempermudah penanganan pedagang pasar tiban

4) Pedagang bersedia ditata sepanjang kebijakan penataan jelas, terarah dan dibarengi penguatan potensi ekonomi sehingga mereka tetap bisa mendapat penghasilan

5) Pemerintah kota memiliki beberapa rencana untuk penataan pasar tiban, hanya perlu diperjelas, dikomunikasikan dengan baik dan dijalankan dengan terencana

Berikut adalah pemaparan hasil kuesioner yang dilakukan di 10 lokasi pasar tiban. Jumlah responden untuk setiap pasar tiban bervariasi mulai dari 4 sampai 8 pedagang. Jumlah total responden adalah 32 pedagang. Jumlah responden tersebut merupakan upaya maksimal yang dilakukan oleh tim peneliti mengingat ketertutupan dan kecurigaan dari pedagang setiap kali ditanyakan perihal pasar tiban. Sebanyak $70 \%$ pedagang telah berdagang lebih dari 5 tahun. Identifikasi lama waktu yang telah digunakan oleh pedagang untuk menggelar daganganya di pasar tiban akan membantu proses komunikasi dan penataan. Mereka yang telah berdagang lebih dari 5 tahun biasanya sudah memiliki pelanggan tetap, omset yang menjanjikan dan ketergantungan antara penjual dengan pembeli yang tinggi. Mereka juga sudah merasa nyaman dengan lokasi berdagang tersebut sehingga enggan untuk pindah. Selain di pasar tiban beberapa pedagang juga berdagang di tempat lain. Beberapa pedagang yang sudah memiliki lokasi berdagang permanen seperti butik, kios, dan lapak di pasar bisa diminta untuk pindah dari pasar tiban dengan segera. Ketika terjadi relokasi atau penataan pasar tiban mereka bisa memiliki alternatif berdagang di tempat lain. Bagi mereka yang tidak memiliki lokasi berdagang lain harus diberikan prioritas dalam penataan pasar tiban.

Sebanyak $63 \%$ pedagang berasal dari Kota Pekalongan dan 37\% dari luar kota. Para pedagang dari luar kota mengetahui lokasi pasar tiban dari saudara atau kerabat yang tinggal di kota Pekalongan. Mereka berasal dari Batang, Wiradesa, Comal, Pemalang, Sukorejo, Kendal. Asal-usul pedagang ini penting untuk mengetahui prioritas penataan.

Tingkat pengetahuan pedagang pasar tiban terhadap rencana penataan masih beragam. Di beberapa lokasi tingkat pengetahuan mencapai $100 \%$ sementara di lokasi lain masih bervariasi. Perbedaan tingkat pengetahuan dimungkinkan kurang intensifnya upaya sosialisasi sehingga belum semua pedagang mengetahui rencana tersebut. Hal ini tentunya membutuhkan upaya lebih kuat dari segenap stakeholder untuk mensosialisasikan rencana penataan pasar tiban. Ketidaktahuan mereka menyangkut konsep penataan secara utuh. 
Beberapa pedagang mengetahui kalau mereka akan ditata di beberapa lokasi seperti Sorogenen. Sementara sebagian yang lain masih belum tahun lokasi yang akan digunakan untuk menempatkan mereka jika dilarang berdagang di lokasi pasar tiban.

Upaya musyawarah tentang rencana penataan pedagang pasar tiban telah dilakukan oleh Pemerintah Kota Pekalongan. Sebanyak $75 \%$ pedagang mengakui pernah diajak musyawarah sedangkan $25 \%$ mengaku belum pernah. Satpol PP, Pemerintah Kota dan Paguyuban disebut sebagai pihak yang telah mengajak pedagang untuk bermusyawarah. Meski demikian jumlah pedagang yang belum pernah diajak musyawarah juga masih cukup signifikan. Ini menjadi pekerjaan yang harus dituntaskan sehingga semua pedagang bisa terlibat dalam pengambilan keputusan. Musyawarah ini penting agar mereka tidak merasa dipinggirkan dan tidak diakui aspirasinya.

Para pedagang mengetahui alasan mengapa mereka harus ditata. Mereka menyadari kalau berdagang di jalan menyebabkan kemacetan, mengganggu ketertiban, menganggu kenyamanan, mengganggu akses masuk pemilik rumah dan beragam akibat lainnya. Meski demikian mereka beranggapan bahwa upaya pemindahan bukanlah solusi terbaik. Mereka bisa ditata di lokasi tanpa harus pindah. Beberapa pedagang menganggap bahwa alasan pemindahan tidak masuk akal. Mereka sudah berdagang bertahuntahun dan baru diminta pindah sekarang. Alasan-alasan keengganan pedagang ini bisa dimaklumi meski sebenarnya tidak bisa dijadikan pembenar untuk melanggar aturan yang berlaku.

Di beberapa lokasi pasar tiban, pedagang menyatakan bahwa mereka bersedia pindah. Mereka menyadari bahwa kegiatan berdagang dengan menggunakan jalan telah mengganggu lalu lintas. Karena itu mereka bersedia dipindah dengan catatan bahwa lokasi mereka pindah tetap ramai dengan pengunjung. Beberapa pedagang bersikukuh bahwa mereka tidak mau pindah dari lokasi pasar tiban yang telah mereka tempati bertahun-tahun. Kesediaan mereka pindah perlu diapresiasi sehingga tidak menimbulkan konflik ketika pemindahan. Pilihan pedagang pasar tiban yang dianggap ideal sebagai lokasi berdagang baru adalah kios di pinggir jalan, kios di lapangan ramai, kios di pasar tradisional dan lokasi yang ramai penduduk lainnya. Bagi mereka yang sudah memiliki kios di pasar tradisional tentunya tidak diprioritaskan. Mereka sudah memiliki tempat untuk berjualan ketika terjadi pemindahan. Disinilah dibutuhkan adanya pendataan yang akurat tentang keberadaan pasar tiban.

Terkait tata cara pemindahan juga harus dikomunikasikan dengan baik antara pemerintah dengan pedagang pasar tiban. Beberapa pedagang menghendaki pemindahan dilakukan oleh pemerintah. Sebagian yang lain menghendaki pindah sendiri sehingga kondisi barang-barang mereka lebih terjaga. Sebagai contoh pedagang di Kandang Panjang yang 100\% memilih untuk pindah sendiri. Sementara pedagang di Dekoro 100\% menghendaki dipindah oleh pemerintah.

Terkait aktifitas pedagang di paguyuban ternyata responya beragam. Pedagang di Pasirsari dan Kandang Panjang mengatakan bahwa mereka tidak aktif di paguyuban pedagang. Sebanyak 90\% pedagang menagku tidak aktif di paguyuban sedangkan $10 \%$ mengaku aktif. Artinya keberadaan paguyuban tidak merepresentasikan secara utuh kebaradaan pedagang. Sehingga dalam proses musyawarah maupun pemindahan paguyuban tetap dilibatkan meski tidak mutlak sebagai wakil seluruh pedagang. 


\section{PEMBAHASAN}

Selama persoalan struktural belum dapat dipecahkan, maka kegiatan ekonomi informal, khususnya perdagangan jalanan akan tetap menjadi sebuah fenomena perkotaan yang tidak dapat dihindarkan. Oleh karena itu, pedagang baik lokal maupun pendatang, perlu diakui keberadaannya dan diperhitungkan dalam perencanaan tata ruang kota. Apalagi perdagangan kaki lima memiliki peran ekonomi penting bagi kelangsungan ekonomi masyarakat, tidak hanya terbatas pada masyarakat perkotaan juga pedesaan. Sehingga berbagai kebijakan pemerintah yang cenderung menghilangkan keberadaan mereka tidak hanya akan mengancam kelangsungan hidup pedagang jalanan, juga dapat mengganggu perkembangan ekonomi secara umum. Adapun kebijakan pemerintah bisa diarahkan untuk menyeimbangkan hubungan ekonomi formal - informal agar tidak eksploitatif, mengingat semakin banyak pedagang jalanan atau pelaku ekonomi informal yang menjadi kepanjangan tangan dari perusahaan-perusahaan besar (Bromley 1979; Castells dan Portes 1989).

Dalam laporan penelitian ini juga terlihat bahwa pemerintah Kota Pekalongan (negara) mencoba berperan dalam mengatur pedagang jalanan. Namun, peran tersebut tidak sepenuhnya berhasil dijalankan karena pemerintah belum memiliki visi yang jelas dalam menangani keberadaan pedagang jalanan. Berbagai kebijakan yang dipilih masih terlihat mendua, antara memasukkan (inclusion) dan mengeluarkan atau menggusur (exclusion) pedagang dalam tata ruang kota. Di sisi lain, tekanan terhadap keberadaan pedagang ternyata mendorong berbagai upaya pengorganisasian pedagang. Meskipun organisasi yang ada sekarang, masih jarang dilibatkan secara langsung dalam proses pembuatan kebijakan dan belum mampu memperjuangkan hak, pengakuan dan perlindungan terhadap keberadaan pedagang.

Perencanaan sektor informal sebagai bagian dari perencanaan kota Pekalongan sangat penting dilakukan. Terdapat hubungan harmonis antara pedagang pedagang dan warga masyarakat Pekalongan terutama dalam pemenuhan kebutuhan sehari-hari dan perlu diakomodasi di dalam perencanaan penataan ruang Kota Pekalongan. Di kalangan pengambil kebijakan sendiri belum memiliki arah yang jelas dalam penanganan pasar tiban. Mereka tidak yakin bahwa upaya yang mereka lakukan akan berhasil karena tidak ada perencanaan matang, lemahnya kordinasi dan dukungan kebijakan yang jelas. Para pedagang harus yakin bahwa segala upaya yang dilakukan Pemkot adalah bertujuan untuk kebaikan semua. Untuk meyakinkan mereka membutuhkan strategi komunikasi yang jelas dan benar. Dalam perencanaan strategi komunikasi diawali dengan riset pendahuluan dan diakhiri dengan riset evaluasi.

Strategi komunikasi adalah kegiatan atau kampanye komunikasi yang sifatnya informasional maupun persuasif untuk membangun pemahaman dan dukungan terhadap suatu ide, gagasan atau kasus, produk maupun jasa yang terencana yang dilakukan oleh suatu organisasi baik yang berorientasi laba maupun nirlaba, memiliki tujuan, rencana dan berbagai alternatif berdasarkan riset dan memiliki evaluasi. Gambaran perencanaan kegiatan komunikasi biasa widujudkan dalam Piramida Komunikasi yang mencakup 6 langkah yaitu: Identifikasi infrastruktur komunikasi , Menentukan tujuan, Target kegiatan,Menentukan target audience, Framing the issue dan Message. Terkait dengan strategi komunikasi penanganan pemindahan pasar tiban Kota Pekalongan perlu disusun langkah-langkah sebagai berikut: 
1. Mengidentifikasi

infrastruktur komunikasi yang ada di Pemerintah Kota Pekalongan

2. Menentukan tujuan dari kegiatan komunikasi, apakah untuk mempengaruhi pedagang agar secara sukarela mau dipindahkan atau memberikan pemahaman bahwa tindakan mereka berdagang di jalanan mengganggu kepentingan lalu lintas sehingga harus dipindahkan.

3. Target kegiatan diperjelas seperti perubahan perilaku, misalnya pedagang mendukung rencana pemindahan dan penertiban

4. Menentukan target audiens berarti memilih pihak yang tepat sebagai sasaran kegiatan komunikasi. Dalam hal ini harus dipastikan bahwa pesan komunikasi tersampaikan kepada pedagang dengan jelas, tepat dan tidak bias kepentingan.

5. Mengemas isu penting dilakukan agar tidak muncul pemahaman bahwa penertiban pedagang pasar tiban adalah bentuk penindasan. Isu dikembangkan bahwa penertiban pasar tiban adalah untuk kebaikan semua baik pedagang, pengguna jalan, pemerintah maupun masyarakat pada umumnya.

6. Mengemas pesan dengan bahasa, symbol dan ungkapan yang tepat. Dalam hal terkandung bahwa pesan harus jelas, mudah dipahami dan mengena pada sasaran.

Berikut adalah taktik yang digunakan dalam strategi komunikasi penanganan pemindahan pedagang pasar tiban di Kota Pekalongan.

\section{TAHAP 2}

Taktik 1: Interpersonal communications

Mengundang pedagang pasar tiba untuk musyawarah

Berikan bantuan secara langsung kepada pedagang pasar tiban yang kurang mampu berupa permodalan dan sarana berdagang

Berikan edukasi melalui sekolah kepada siswa tentang pentingnya menjaga tertib lalu lintas. Anak-anak akan menyampaikannya kepada orang tua mereka

Ajaklah pedagang untuk berdialog terbuka, saling menghargai dan bukalah hati dan pemikiran mereka agar mereka paham bahwa tindakan berdagang di jalan raya tidak dibenarkan

Gunakan pendekatan human relation, hindari penggunaan power relation.

Memanfaatkan pemuka agama, tokoh masyarakat, LSM, kepolisian sebagai endorser.

Taktik 3: News media

Bekerjasama dengan media yang ada di Kota Pekalongan seperti Radar Pekalongan, Suara Merdeka, Radio, TV untuk membentuk opini public bahwa penataan pasar tiban adalah untuk kebaikan bersama, tidak mematikan pedagang

Memanfaatkan social media seperti facebook dan twitter. Ini juga bermanfaat karena sebagian pedagang pasar tiban berusia muda dan aktif di social media

Isi dari pemberitaan bersifat liputan, opini maupun feature yang mendukung penataan pasar tiban
Taktik 4. Tactic advertising and promotional media

Beriklan dan berpromosi di media lokal Pekalongan

Iklan hanya sebagai pendukung dari taktik yang lain

Gambar: Taktik yang digunakan dalam strategi komunikasi permasalahan pasar tiban yg berisi pentingnya ketertiban, tanggapan masyarakat, $\quad$ tokoh ditayangkan di Batik TV dan diunggah ke website.

Jika sudah memiliki gambar atau sketsa pemindahan, bisa disertakan

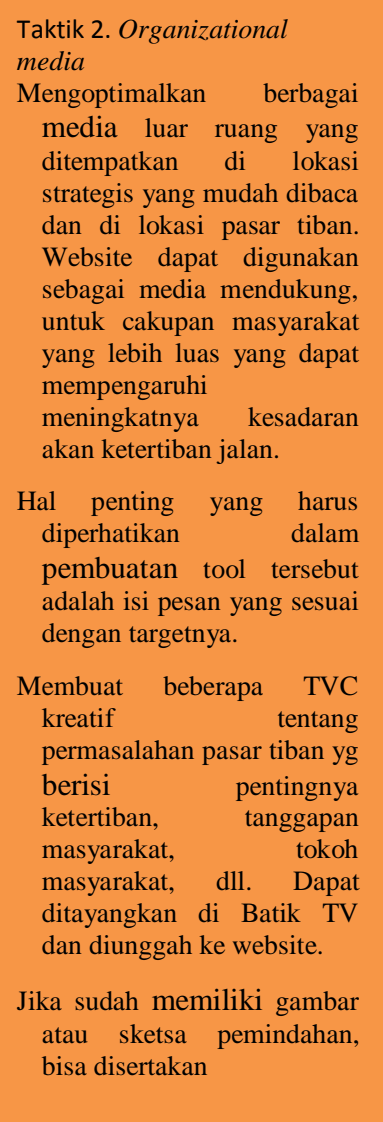

Taktik 2. Organizational

Mengoptimalkan berbagai media luar ruang yang ditempatkan di lokas strategis yang mudah dibaca Website dapat digunakan sebagai media mendukung, untuk cakupan masyarakat mempengaruhi meningkatnya kesadaran akan ketertiban jalan.

al penting yang harus adalah isi pesan yang sesua dengan targetnya.

embuat beberapa TVC

\section{asi}




\section{SIMPULAN}

Berikut simpulan hasil penelitian: pedagang sesungguhnya bersedia ditata jika arah penataan jelas dan mampu meningkatkan kesejahteraan mereka. Karena itu diperlukan kordinasi dan kejelasan arah kebijakan yang diambil oleh pemerintah Kota Pekalongan, strategi komunikasi yang tepat dalam menangani pedagang pasar tiban, dan strategi komunikasi bisa dilaksanakan jika tujuan didefinisikan dengan jelas.

\section{DAFTAR PUSTAKA}

Breman, Jan. (2001). “An Informalised Labour System: End of Labour Markt Dualism." Economic and Political Weekly 36 (52) : 4801 4821.

Brotosunaryo, PM, Wahyudin, Sariffudin, "Strategi Penataan dan Pengembangan Sektor Informal di Kota Semarang”, Jurnal Riptek Vol. 7, No. 2, Tahun 2013, Hal. 71 - 80

Bromley, Ray. (1979). "Organization, Regulation and Exploitation in the So-Called 'Urban Informal Sector': The Street Traders of Cali, Colombia." The Urban Informal Sector: Critical Perspectives on Employment and Housing Policies. R. Bromley. Oxford, Pergamon Press: 1161-1172.

Castells, Manuel dan Alejandro Portes. (1989). "World Underneath: The Origins,Dynamics, and Effects of the Informal Economy." The Informal Economy: Studies in Advance and Less Developed Countries. Alenjandro Portes, Manuel Castells, and Lauren A. Benton. London, The Johns Hopkins University Press: 1137.
Cross, John C. (1998). "Co-optation, Competition, and Resistance: State and Street Vendors in Mexico City." Latin American Perspectives 25 (2): 41-61.

Davis, Mike. (2004). "Planet of Slums: Urban Involution and the Informal Proletariat." New Left Review 26: 5-34.

Firdausy, C. M. (1995). Pengembangan Sektor Informal Pedagang Kaki Lima di Perkotaan. Jakarta, Dewan Riset Nasional dan Bappenas Puslitbang Ekonomi dan Pembangunan LIPI.

Handayani, Suci. (2006). Pelibatan Masyarakat Marginal dalam Perencanaan dan Penganggaran Partisipatif: Sebuah Pengalaman di Kota Solo. Solo, KOMPIP dan The Ford Foundation.

Hugo, Graeme J. (1991). "Partisipasi Kaum Migran dalam Ekonomi Kota di Jawa Barat." Urbanisasi, Pengangguran, dan Sektor Informal di Kota. Chris Manning dan Tadjuddin Noer Effendi. Jakarta, Yayasan Obor Indonesia.

ILO. (2007). Labour and Social Trends in Asean 2007: Integration, Challenges and Opportunities. Bangkok: ILO.

Kotler, Phillip. Marketing Management. The Millenium Edition. The Prentice Hall International. USA. 2000.

Kusakabe, Kyoko. (2006). Policy Issues on Street Vending: An Overview of Studies in Thailand, Cambodia, and Mongolia. Bangkok, ILO.

Manning, Chris and Tadjuddin Noer Effendi. (1991). Urbanisasi, Pengangguran, dan Sektor Informal 
di Kota. Jakarta, Yayasan Obor Indonesia.

Moser, Caroline N. (1979). "Informal Sector or Petty Commodity Production: Dualism or Dependence in Urban Development?" The Urban Informal Sector: Critical Perspectives on Employment and Housing Policies. R. Bromley. Oxford, Pergamon Press: 1041-1064.

Pena, S. (1999). 'Informal Markets: Street Vendors in Mexico City." Habitat International 23 (3): 363-372.

Priyono, Edy. (2002). "Mengapa Angka Pengangguran Rendah di Masa Krisis: Menguak Peranan Sektor Informal sebagai Buffer Perekonomian.” Jurnal Ekonomi dan Kewirausahaan 1 (2).

Rachbini, Didik J. dan Abdul Hamid. (1994). Ekonomi Informal Perkotaan: Gejala Involusi Gelombang Kedua. Jakarta, LP3ES.

Rukmana, Deden. 2008. "PKL dan Informalitas Perkotaan”. Diunduh dari

http://www.jakartabutuhrevolusibuda ya.com/2008/04/03/pedagang-

kakilima-daninformalitasperkotaan/. Diakses pada 19 Agustus 2014

Setia M, Resmi. 2013. Ekonomi Informal Perkotaan: Sebuah kasus tentang pedagang kaki lima di Kota Bandung. Available at http://www.akatiga.org/index.php/ha sil-penelitian/item/294-ekonomiinfromal-perkotaan-sebuah-studikasus-tentang-pedagang-kaki-limadi-kota-bandung?highlight Diakses pada 19 Agustus 2014

Skinner, Caroline. (2008). "The Struggle for the Streets: Processes of
Exclusion and Inclusion of Street Traders in Durban, South Africa." Development Southern Africa 25 (2): 227-242.

Smith, D. Ronald. Strategic Planning For Public Relations. Second Edition. Lawrence Erlbaum Associates Publisher. London. 2005

Todaro, Michael P. dan Jerry Stilkind. (1991). "Dilema Urbanisasi." Pengangguran, dan Sektor Informal di Kota. Chris Manning dan Tadjuddin Noer Effendi. Jakarta, Yayasan Obor Indonesia: 4-33. 